УДК:330.837

DOI: https://doi.org/10.32782/2415-8801/2021-1.5

Ільїна М.В.

доктор економічних наук, старший науковий співробітник, завідувач відділу екосистемного

оичнювання природно-ресурсного потенціалу,

ДУ «Інститут економіки природокористування та сталого розвитку Національної академії наук України»

Шпильова Ю.Б.

доктор економічних наук, стариий науковий співробітник відділу проблем економіки земельних і лісових ресурсів, ДУ «Інститут економіки природокористування та сталого розвитку Національної академії наук України»

\author{
СОЦІАЛЬНІ ЕФЕКТИ ПЛАТФОРМЕННОЇ ВЗАЕМОДІЇ \\ ПРИРОДНО-РЕСУРСНОГО ТА РИНКОВОГО ЦИКЛІВ РОЗВИТКУ
}

У статті визначено ключові аспекти соціальних перетворень, щцо виникають як результат посилення взаємозв'язку між використанням природного ресурсу і функціонуванням ринків в умовах цифрової економіки. Обтрунтовано чинники впливу на процеси інтеграції системи використання природних ресурсів до зони впливу ринку. Розкрито соціальні ефекти платформенної взаємодії системи природокористування та ринку для населення й органів державної влади, які мають прояв як на рівні окремих територій, так $і$ на рівні держави. Зроблено висновок, що забезпечення економічного розвитку краӥни на основі інтеграції системи використання природних ресурсів до ринкового середовища потребує диференційованого підходу до територіальних громад різного розміру та ступеня урбанізації, які мають різну кадрову, фінансову і технологічну потужність щцодо цифровізацї місцевої економіки. Запропоновано найбільи ефективні інструменти інтеграції системи використання природних ресурсів до зони впливу ринку на основі цицфрових технологій.

Ключові слова: цүифрова економіка, соціальний ефект, платформа взаємодії, природний ресурс, територіальна громада.

\title{
SOCIAL EFFECTS OF THE PLATFORM INTERACTIONS BETWEEN NATURAL RESOURCE USE AND MARKET CYCLES
}

\author{
Ilina Mariia, Shpyliova Yuliia \\ Public Institution «Institute of Environmental Economics and \\ Sustainable Development of the National Academy of Sciences of Ukraine»
}

The paper identifies key aspects of social changes occurring as the result of strengthening the relations between natural resources' use and markets' functioning in the digital economy framework. The traditional model of the market's interaction with the system of natural resources use is transformed, and the new socio-economic place is established. Main indicators of the process are changes in GDP and employment in various sectors of the economy, modification of the knowledge and information sector into the important factor of production and economic growth, and emergence of the competitiveness. It is concluded the economy's digitalization is able to ensure more efficient use of natural resources and consequently provide more revenues - primarily due to better assessment and accounting of natural resources and their conservation. However, the digitalization can occur only if special investment and innovation policy, which presumes integration of the science and industry, development of an internal market of high technologies and application of financial instruments. Factors powering the process of integration of the system of natural resources use into the zone of market influence are substantiated. Social effects of the platform interaction of the nature management system and the market for the population, public authorities and the government have been discovered. The maximum effect of their implementation into the processes of market interaction with natural resources should be preceded by structural transformation of the economy, shifting approaches to management of relevant innovations, imperfection of the nature management model and adaptation of the education system. In order to ensure the country's economic development through integration of natural resources into the market framework the differentiated approach is needed to separate policies for local communities of different size and degrees of urbanization, since they have unlike human, financial and technological capacities to digitize local economies. The most effective tools for integrating the system of natural resources use into the market area on the basis of digital technologies have been proposed.

Keywords: digital economy, social effect, interaction platform, natural resource, territorial community. 
Постановка проблеми. Стійке функціонування будь-яких систем (ринкової, використання природних ресурсів) повинно мати чіткий взаємозв'язок і взаємозалежність усіх їхніх складників, спрямованих на реалізацію поставлених цілей. Унаслідок таких взаємозв'язків між розвитком ринку і способами використання природних ресурсів виникають різноспрямовані ефекти, серед яких на особливу увагу заслуговують соціальні. Розвиток цифрової економіки нерозривно пов'язаний із формуванням інформаційного суспільства та платформенною взаємодією природно-ресурсного та ринкового циклів розвитку.

Суттю цифрової економіки є іiі функціонування 3 повсюдним використанням інформаційно-комунікаційних технологій, які трансформують традиційну економіку від тієї, що споживає ресурси, до такої, яка ресурси створює. Ключовим ресурсом цифрової економіки $\epsilon$ інформація, яка генерується та забезпечує взаємодію між економічними суб'єктами завдяки функціонуванню електронно-цифрових пристроїв, засобів та систем. Тому формування сучасної виробничої моделі інформаційного суспільства передбачає створення відповідної технологічної інфраструктури, унормування та врегулювання процесів використання баз даних, підготовку користувачів та фахівців, що, крім іншого, займатимуться організацією технологічних платформ. Перелічені процеси впливатимуть на взаємодію ринку із системою використання природних ресурсів, а також матимуть певні соціальні наслідки.

Аналіз останніх досліджень і публікацій. Ocoбливості розвитку цифрової економіки в Україні та практичні дослідження відповідної трансформації суспільства під впливом цифровізації відображено у наукових працях вітчизняних та зарубіжних учених, зокрема T.І. Батракова, О.В. Карпенко, Н.М. Краус [1], К.М. Краус [2], В.П. Куприяновського, В.С. Куйбіди [3], Л.О. Матвейчук [4], А.О. Маслова [5], В.В. Наместник, О.В. Сакаль, С.А. Синягова, А.М. Сундука, М.А. Хвесика [6]. Але водночас багато питань щодо визначення соціальних ефектів платформенної взаємодії природно-ресурсного та ринкового циклів розвитку в умовах цифрової економіки залишаються недостатньо дослідженими.

Постановка завдання. Метою статті є дослідження основних принципів формування інформаційного суспільства та цифровізації економіки України, встановлення соціально-економічних наслідків від інтеграції природних ресурсів до зони впливу ринку в умовах цифрової економіки. Незважаючи на зростання кількості праць, залишаються недостатньо дослідженими й потребують більш глибокого вивчення система ефектів та розроблення інструментів інтеграції природних ресурсів до зони впливу ринку на основі цифрових технологій.

Виклад основного матеріалу дослідження. Традиційно засади функціонування, цілі та засоби ринкової економіки і природокористування як сфери виробничої діяльності є різноспрямованими, суперечливими та складно узгоджуваними між собою. Такі протиріччя мають певні соціальні (суспільно значущі) наслідки, що можуть загострюватися або, навпаки, нівелюватися в епоху цифрової економіки та технологічних змін.

В умовах інформаційного суспільства основними ознаками формування нового соціально-економічного простору, де відбувається трансформація традиційної моделі взаємодії ринку із системою використання природних ресурсів, є: зміна структури ВВП та зайнятості в секторах економіки, зокрема зростання нематеріального виробництва та сфери послуг; перетворення знань та інформації на вагомий чинник виробництва на противагу більш традиційним факторам (землі, засобів виробництва, капіталу). Важливими властивостями інформаційного чинника є його здатність проникати у традиційні, суттєво підвищуючи їх ефективність; перетворення інформації на вагомий чинник економічного зростання i конкурентоспроможності національної економіки; актуалізація потреби навчання громадян цифровій грамотності, у тому числі протягом життя. Інформаційна освіта стає видом інвестицій у людський капітал, здатним суттєво підвищувати ефективність виробництва і частку наукоємної продукції у структурі ВВП; сприяє виникненню нових професій (експертів 3 інформаційних технологій); зміні характеру праці, його деформалізації, гнучкості робочого графіку, поширенню часткової зайнятості та віртуальної форми організації праці; зростанню ролі інформаційних технологій і мереж у державному управлінні та виробництві (передача інформації за допомогою телекомунікацій, упровадження електронних платіжних систем, поява «віртуальних підприємств» - цифрових платформ).

Цифровізація економіки здатна забезпечити більш ефективне використання природних ресурсів та отриманих від цього доходів, насамперед за рахунок оцінки й обліку природних ресурсів та їх охорони. Прикладом цього може слугувати передбачена законопроєктом про внесення змін до деяких законодавчих актів України щодо підтримки розвитку вітчизняних галузей надрокористування інтерактивна карта корисних копалин України - інформаційний ресурс, що відображатиме відомості про державні фонди надр та родовищ корисних копалин, межі земельних ділянок, запаси корисних копалин, спеціальні дозволи на користування надрами тощо. Така інформація, доступ до неї та її використання дають змогу зменшити протиріччя між ринковим та природно-ресурсним середовищем. Наприклад, за допомогою інформаційних технологій можна більш точно визначити поточні доходи від інтеграції природних ресурсів до зони впливу ринку та спрогнозувати потенційні наслідки. Однак таку цифровізацію може забезпечити лише цілеспрямована інвестиційно-інноваційна політика, що включатиме інтеграцію науки та виробництва, розвиток внутрішнього ринку високих технологій, фінансових інструментів.

Під інтеграцією природних ресурсів до зони впливу ринку слід розуміти їх раціональне, екологічно орієнтоване господарське використання 3 максимально можливим економічним ефектом, що забезпечуватиметься саме завдяки залученню до цього процесу цифрових технологій та враховуватиме сукупність чинників впливу (рис. 1).

Окрім економічних та екологічних ефектів такої інтеграції, мають бути враховані ще й соціальні. Соціальні ефекти платформенної взаємодії системи природокористування та ринку полягатимуть: для населення - у зростанні зайнятості (у високотехнологічних галузях), підвищенні якості життя та середовища проживання; для підприємств і організацій - у зростанні рівня доходів працівників завдяки підвищенню еко- 


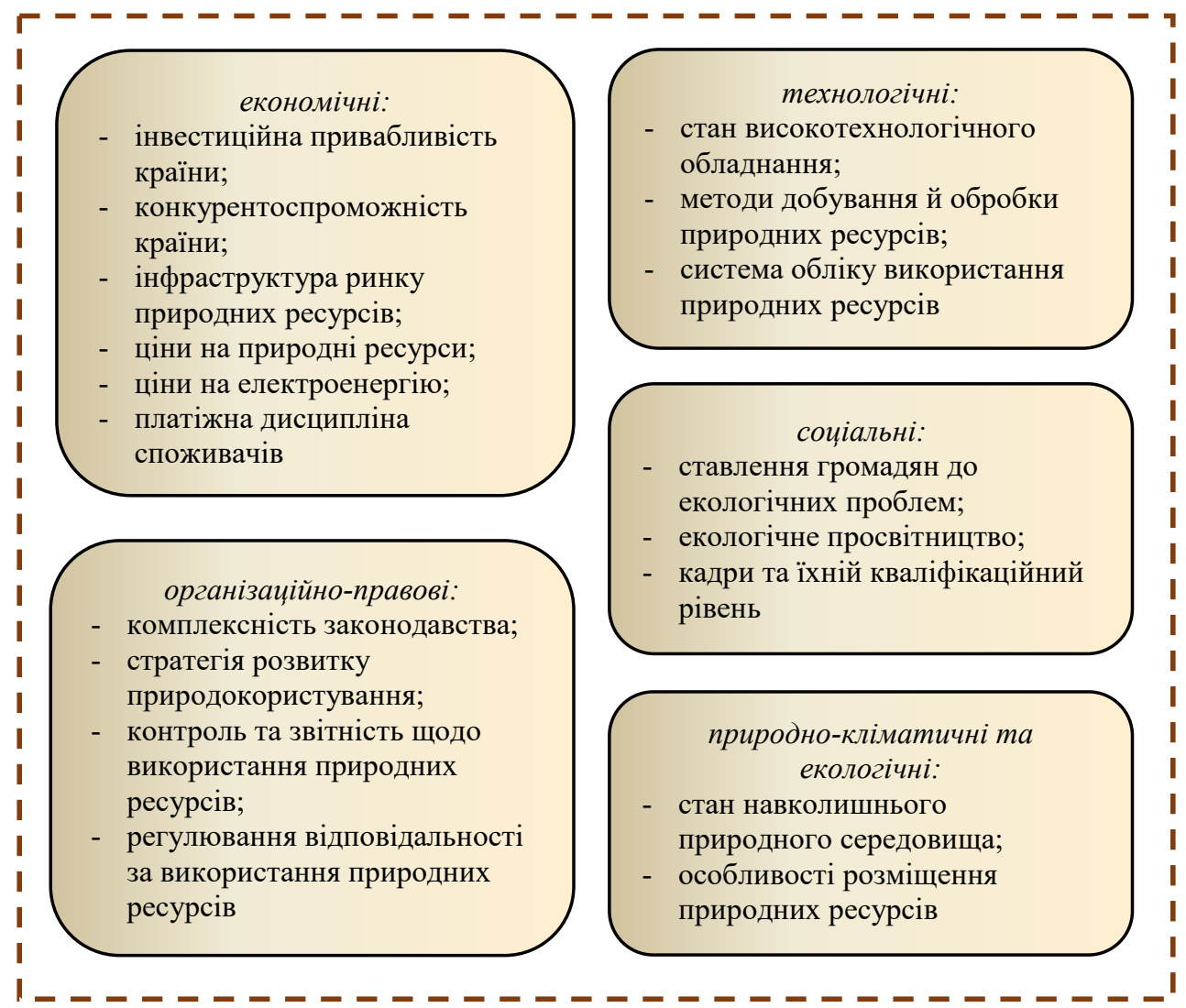

Рис. 1. Чинники впливу на процеси інтеграції системи використання природних ресурсів до зони впливу ринку

Джерело: розроблено авторами

номічної ефективності суб“єктів господарювання; для регіональних та місцевих органів державної влади - у зміцненні фінансової спроможності.

Перелічені соціальні ефекти, на нашу думку, є функцією не ринку, а держави, зокрема в частині реалізації політики цифровізації економіки. Такі соціальні ефекти від поліпшення взаємодії природно-ресурсного та ринкового циклів розвитку мають свій прояв як на рівні окремих територій, так і на рівні держави (табл. 1).

Соціально-економічні наслідки позитивного характеру від інтеграції природних ресурсів до зони впливу ринку в умовах цифрової економіки включають: тех- нологічне зміцнення та пришвидшення виробничих зв'язків між підприємствами, суспільством та державою; гарантування безпеки електронного документообігу; підвищення рівня прибутковості підприємств завдяки прискоренню виробничих процесів та їх автоматизації; підвищення якості життя населення завдяки поліпшенню побутових умов, рівня освіти, урізноманітнення дозвілля.

Таким чином, соціальні ефекти від інтеграції природних ресурсів до зони впливу ринку значною мірою зумовлені процесами цифровізації економіки, стрімким накопиченням обсягів та поширенням інформації

Таблиця 1

Система ефектів інтеграції природних ресурсів до зони впливу ринку в умовах цифровізації економіки

\begin{tabular}{|c|c|c|}
\hline \multicolumn{2}{|c|}{ Соціальні ефекти для } & \multirow{2}{*}{ Інші ефекти } \\
\hline системи природокористування & сфери ринку & \\
\hline $\begin{array}{l}\text { Охорона та захист довкілля завдяки участі } \\
\text { в міжнародних екологічних проєктах }\end{array}$ & $\begin{array}{l}\text { Залучення іноземних інвестицій для екологічних } \\
\text { інновацій }\end{array}$ & Фінансові \\
\hline $\begin{array}{l}\text { Екологізація виробничих процесів завдяки } \\
\text { впровадженню новітніх технологій }\end{array}$ & $\begin{array}{l}\text { Зростання кількості та потужності виробництв } \\
\text { у сфері екологічного підприємництва }\end{array}$ & Виробничі \\
\hline $\begin{array}{l}\text { Скорочення обсягів використання природних } \\
\text { ресурсів та зменшення експорту сировини } \\
\text { завдяки збільшенню виробництва готової } \\
\text { продукції з високою доданою вартістю }\end{array}$ & $\begin{array}{l}\text { Залучення невикористаних раніше природних } \\
\text { ресурсів, у першу чергу земельних та водних, } \\
\text { до економічної діяльності (зокрема, завдяки } \\
\text { впровадженню геокадастрів) }\end{array}$ & $\begin{array}{c}\text { Раціонального } \\
\text { природокористування }\end{array}$ \\
\hline $\begin{array}{l}\text { Поліпшення стану довкілля завдяки підвищенню } \\
\text { якості контролю використання природних } \\
\text { ресурсів }\end{array}$ & $\begin{array}{l}\text { Оптимізація обсягів рентних платежів завдяки } \\
\text { підвищенню якості контролю використання } \\
\text { природних ресурсів }\end{array}$ & Контролю \\
\hline
\end{tabular}

Джерело: розроблено авторами 
за допомогою новітніх технологій. Отриманню максимального ефекту від їх упровадження у процеси взаємодії ринку з природними ресурсами мають передувати структурна перебудова економіки, зміна підходів до управління відповідними інноваціями, трансформація моделі природокористування, а також адаптація системи освіти населення. Із цією метою до рекомендованих заходів із модернізації вітчизняної економіки належать: захист майнових прав, у тому числі тих, що стосуються інформації (права на доступ до неї, володіння та авторство); створення сприятливого економічного середовища та впровадження відповідних фінансових інструментів для розвитку наукомістких галузей та інформаційних технологій; підвищення частки інженерно-технічних і науково-практичних працівників у структурі зайнятих; розширення доступу до спеціалізованої освіти та поширення серед громадян знань та навиків використання цифрових технологій.

Оскільки залучення до процесу природокористування суб“єктів економічної діяльності виявляється суттєво опосередкованим доступом до інформації, остання як ключовий чинник інтеграції системи використання природних ресурсів до ринкових структур завдає суттєвих змін у характері соціальних зв'язків та відносин. У цьому аспекті важливим питанням, яке має контролювати держава, є ступінь відчуженості (або залученості) населення (у першу чергу місцевих громад) від використання природних ресурсів. На нашу думку, у цьому відношенні вдосконалення вимагають насамперед: методики розрахунку платежів за використання природних ресурсів та порядку ліцензування; посилення відповідальності за несанкціонований видобуток та переробку природних ресурсів; упровадження додаткових фінансових інструментів стимулювання інноваційно-інвестиційної діяльності у сфері природокористування та забезпечення виконання договірних зобов'язань.

Забезпечення економічного розвитку країни на основі інтеграції системи використання природних ресурсів до ринкового середовища потребує диференційованого підходу до територіальних громад різного розміру (великих, середніх, малих) та ступеня урбанізації (міських, сільських, заміських), які мають різну кадрову, фінансову i технологічну потужність щодо цифровізації місцевої економіки. Водночас потреба в опануванні навичок управління цифровими технологіями зростає по відношенню як до органів місцевої влади, так і членів громад. Наприклад, законопроєктом про внесення змін до Земельного кодексу України та інших законодавчих актів щодо вдосконалення системи управління та дерегуляції у сфері земельних відносин передбачено надання повноважень зі здійснення державного контролю над використанням та охороною земель виконавчим органам сільських, селищних, міських рад, а також перехід до розроблення документації iз землеустрою та технічної документації 3 оцінки земель винятково в електронному форматі.

Більше того, концепція реформування системи державного нагляду (контролю) у сфері охорони навколишнього середовища в Україні включає передачу окремих функцій природоохоронного контролю місцевим громадам, зокрема в частині контролю стану об'єктів природно-заповідного фонду місцевого значення, полювання, браконьєрства, поводження з відхо- дами з відповідним звітуванням перед громадськістю. Тому першим етапом цифрової трансформації територіальних громад $є$ підвищення цифрових навичок посадових осіб органів місцевого самоврядування 3 метою поліпшення ефективності їхньої роботи, збереження грошей платників та розвитку «розумних міст». Другий етап передбачає забезпечення рівного доступу громадян до електронних послуг, електронної демократії, підвищення цифрових навичок населення. Водночас для системи освіти основним завданням на шляху цифровізації економіки є іiі забезпечення відповідними кваліфікованими кадрами. Незадоволений попит на ринку праці на такі кадри свідчить про їх нестачу, а також про брак взаємозв“язку з фахівцями 3 економіки, соціальних наук, науковцями, що здійснюють міждисциплінарні дослідження.

Найбільш ефективним інструментом інтеграції системи використання природних ресурсів до зони впливу ринку на основі цифрових технологій нині є реалізація проєктів регіонального та місцевого розвитку, зокрема за такими напрямами:

диверсифікація джерел енергопостачання та підвищення рівня енергоефективності;

створення індустріальних парків, які для свого функціонування потребують залучення інших підприємств, наприклад водо-, електро-, газопостачання, телекомунікацій;

розроблення містобудівних кадастрів, що надають інформацію про стан і статус об‘ єктів землекористування та нерухомості, екологічні й інженерно-геологічні характеристики окремих територій та земельних ділянок, можливості провадження на них містобудівної діяльності з урахуванням обмежень на підставі екологічних, гідрометеорологічних, радіологічних, санітарно-гігієнічних досліджень, інженерно-геологічного, гідрогеологічного районування;

створення інформаційних баз тепловтрат будівель комунального та житлового фонду міста за даними тепловізійних досліджень;

створення інформаційних порталів районів (територій, громад) як інструменту залучення інвестицій;

розбудова технологічних парків альтернативної енергетики (комунальних сонячних електростанцій);

упровадження автоматизованих систем диспетчерського спостереження та управління обласними виробничими комунальними водопровідно-каналізаційними підприємствами;

побудова моделей інтегрованого управління територією, що особливо актуально у разі планування реалізації масштабних проєктів локального значення (наприклад, поетапної житлової забудови території, створення курорту), які потребують об'ємно-просторової візуалізації інфраструктури наміру, урахування наявних об'єктів, систем комунікацій, ландшафту, руху транспорту, дизайну;

формування логістичної системи для місцевого аграрного виробництва (створення Інтернет-платформ для комунікації між споживачами продукції та сільгоспвиробниками, взаємодія останніх із кооперативними об“єднаннями, організація доставки продукції).

Висновки 3 проведеного дослідження. Перелічені й обгрунтовані заходи та інструменти здатні суттєво підвищити ефективність використання природних ресурсів, поліпшити соціальний стан та економічну 
спроможність територіальних громад, їх взаємодію 3 ринковими інституціями й органами влади, а також покращити ситуацію із цифровізацією окремих сфер вітчизняної економіки загалом. Ключовими аспектами соціальних перетворень, що наступають як результат посилення взаємозв'язку між використанням природного ресурсу і функціонуванням ринків в умовах цифрової економіки, є якісно новий рівень життя населення (характер та умови праці, освіти, особливості дозвілля, побутові умови, соціально-психологічний клімат на підприємствах та ін.); якість взаємозв'язків та взаємодії між підприємствами, суспільством та державою (принцип найбільш повного та своєчасного виконання обов'язків один перед одним, можливості надання нових послуг); безпека документообігу через автоматичні цифрові платформи; економія вільного часу індивідуумів («пом'якшення» трудового навантаження на працівників, підвищення рівня механізації й автоматизації виробництва, системна і комплексна модернізація та реформування системи охорони здоров'я, освіти).

\section{Список використаних джерел:}

1. Голобородько О.П., Краус Н.М., Краус К.М. Цифрова економіка: тренди та перспективи авангардного характеру розвитку. Ефективна економіка. 2018. № 1. URL: http://www.economy.nayka.com.ua/pdf/1_2018/8.pdf (дата звернення: 11.01.2021).

2. Краус Н.М., Краус К.М. Цифровізація в умовах інституційної трансформації економіки: базові складові та інструменти цифрових технологій. Інтелект ХХІ століття. 2018. № 1. С. 211-214.

3. Куйбіда В.С., Карпенко О.В., Наместник В.В. Цифрове врядування в Україні: базові дефініції понятійнокатегоріального апарату. Вісник Національної академї̈ державного управління при Президентові України. Серія «Державне управління». 2018. № 1. С. 5-10.

4. Матвейчук Л.О. Цифрова економіка: теоретичні аспекти. Вісник Запорізького національного університету. 2018. № 4(40). С. 116-127.

5. Маслов А.О. Інформаційна економіка: становлення, структура та теоретичне осмислення : монографія. Київ : Аграр Медіа Гр., 2012. 432 с.

6. Хвесик М.А., Сундук А.М. Доки не пізно... (економіка - екологія - людина). Дзеркало тижня. 2017. № 41 (4-10 листопада). URL: https://dt.ua/ECOLOGY/doki-ne-pizno-ekonomika-ekologiya-lyudina-259082_html (дата звернення: 07.02.2021).

\section{References:}

1. Holoborodko, O. P., Kraus, N. M., Kraus, K. M. (2018) “The digital economy: trends and prospects for the avantgarde nature of development". Efectyvna ekonomika [Online], vol. 1. Available at: http://www.economy.nayka.com.ua/ pdf/1_2018/8.pdf (accessed 11 Jan 2021).

2. Kraus, N.M., Kraus, K.M. (2018) "Digitalization in the context of the institutional transformation of the economy: the basic components and tools of digital technologies". Intellect of the XXI century, no. 1, pp. 211-214.

3. Kuybida, V.S., Karpenko, O.V., Namestnyk V.V. (2018) Digital government in Ukraine: principle definitions of the terms-and-categories list. Visnyk Natsionalhoyi akademiyi derzhavnogo upravlinnia pry Prezydentovi Ukrayiny ("Public administration" series), no. 1, pp. 5-10.

4. Matveychuk, L.O. (2018) Digital economy: theoretical aspects. Visnyk Zaporizkogo natsionalnogo universytetu, no. 4(40), pp. 116-127.

5. Maslov, A.O. (2012). Digital economy: establishment, structure and theoretical thinking. Kyiv : Agrar Media Gr., 432 p.

6. Khvesyk, M. \& Sunduk, A. (2017) Doky ne pizno... (ekonomika - ekolohiia - liudyna) [It's not too late... (economics - environment - human)]. Dzerkalo tyzhnia, 41. Retrieved from: https://dt.ua/ECOLOGY/doki-ne-pizno-ekonomika-ekologiya-lyudina-259082_html (in Ukrainian)

E-mail:maria_ilina@bigmir.net

E-mail: shpuleva_y@ukr.net 